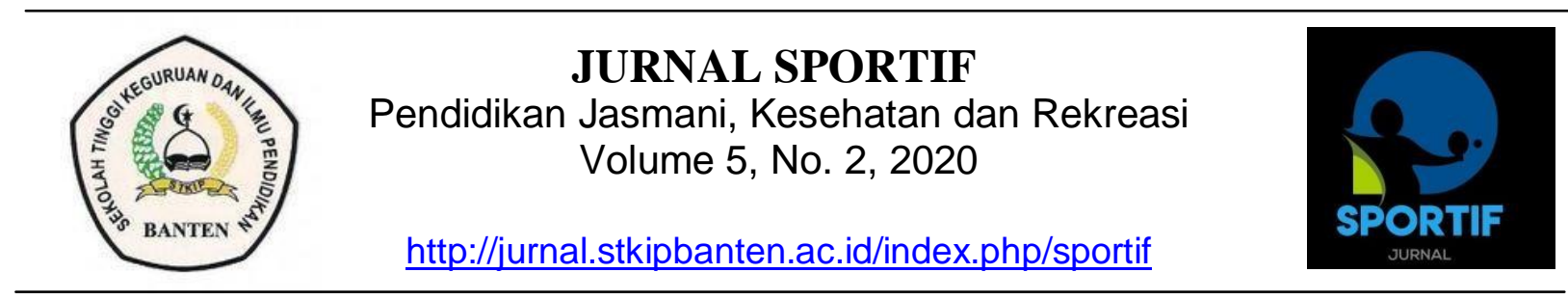

\title{
LATIHAN SMALL SIDED GAMES DALAM KETEPATAN PASSING PADA EKSTRAKURIKULER SEPAK BOLA
}

\author{
Bayan Ardana Wikarta ${ }^{1}$, Muzni Rofik ${ }^{2}$ \\ ${ }^{1}$ Sekolah Tinggi Keguruan dan Ilmu Pendidikan Banten \\ ${ }^{2}$ Mahasiswa, Pendidikan Jasmani, Kesehtan dan Rekreasi \\ $\underline{\text { bayanardana22@gmail.com }},{ }^{2}$ rofik_muzni111@gmail.com
}

\begin{abstract}
ABSTRAK
Sepak Bola merupakan salah satu cabang olahraga yang paling banyak diminati penduduk dunia, tidak terkecuali di Indonesia. Cabang olahraga ini dimainkan oleh masing-masing 11 orang pemain dan dilakukan di sebuah lapangan berumput yang sangat luas. Penelitian ini bertujuan untuk mengetahui pengaruh latihan small sided games terhadap ketepatan passing ekstrakurikuler sepakbola Metode penelitian yang digunakan adalah studi literature. Studi literatur ini dimaksudkan untuk mengungkapkan berbagai teori- teori yang relevan dengan permasalahan yang sedang diteliti. Teknik ini dilakukan dengan cara membaca, mempelajari dan mengkaji literatur-literatur yang berhubungan dengan latihan small slided games dan ketepatan passing. Berdasarkan hasil analisis dari berbagai sumber dapat disimpulkan bahwa Latihan Small Sided Games sangat memberikan pengaruh terhadap Ketepatan Passing Pada Ekstrakurikuler Sepak Bola.
\end{abstract}

Kata Kunci : Latihan Small Sided Games, Ketepatan Passing, Ekstrakurikuler Sepak Bola 


\section{PENDAHULUAN}

Sepak Bola merupakan salah satu cabang olahraga yang paling banyak diminati penduduk dunia, tidak terkecuali di Indonesia. Cabang olahraga ini dimainkan oleh masing-masing 11 orang pemain dan dilakukan di sebuah lapangan berumput yang sangat luas. Olahraga ini berkembang menjadi sangat popular seiring dengan semakin berkembangnya dunia olahraga. Olahraga ini memiliki tujuan, yaitu meraih kemenangan dengan mencetak gol sebanyak mungkin ke gawang lawan yang dibangun dari tiang danberjaring, dengan lebar gawang berukuran 7,32 meter dan tinggi gawang berukuran 2,44 meter. Dalam permainannya, 11 pemain yang bermain dan 11 pemain yang menjadi lawan, yang merumput dalam satu tim terdiri atas 10 pemaindi tengah lapang dan 1 orang penjaga gawang yang bertugas mengamankan gawang dari serangan lawan. Sepakbola digemari berbagai kalangan masyarakat dari kalangan bawah, menengah, sampai kalangan atas, itu yang menyebabkan populernya olahraga sepakbola didunia.

Sepak bola merupakan olahraga tim yang memerlukan kerja sama untuk menyuguhkan permainan menarik dan mendapatkan kemenangan. Seperti yang diutarakan oleh Soedjono (1983:7), sepakbola adalah permainan beregu yang dimainkan oleh maksimal sebelas orang termasuk penjaga gawang dimana masingmasing regu bertujuan memasukkan bola ke gawang lawan dan berusaha mempertahankan gawangnya terhindar dari kemasukan gol oleh pemain lawan. Setiap pemain dituntut untuk dapat melakukan gerakan yang terampil dengan waktu yang terbatas selama 90 menit dalam satu pertandingan. Selain itu para pemain harus mampu menanggapi perubahan situasi permainan yang cepat dan harus memahami taktik permainan individu maupun kerja sama tim. Untuk mendapatkan semua itu, pemain harus menjalani program latihan yang sudah disiapkan dan dirancang oleh pelatih dengan sungguh-sungguh.
Didalam permainan sepak bola modern, kebanyakan tim lebih memaksimalkan passing (umpan) pendek dari pada menggunakan passing (umpan) jauh. Itu dikarenakan passing pendek lebih efektif untuk mengontrol permainan agar tidak mudah kehilangan ball possesion (penguasaan bola). Tanpa menghilangkan pentingnya teknik-teknik sepak bola lainnya, umpan pendek juga memudahkan pemain menerima (mengontrol) dan menguasai bola. Menurut Danny Mielke (2007:18), "umpan atau passing adalah cara memindahkan momentum bola dari satu pemain ke pemain lain". Umpan paling baik dilakukan dengan menggunakan kaki bagian dalam, karena pada kaki bagian dalam terdapat permukaan yang lebih luas bagi pemain untuk menendang bola sehingga memberikan kontrol bola yang lebih baik, meskipun tidak menutup kemungkinan saat berada pada suatu kondisi tertentu atau situasi sulit untuk melakukan umpan dengan kaki, bagian tubuh lain juga dapat digunakan.

Penguasaan bola sebuah tim sangat berpengaruh terhadap sebuah hasil dalam pertandingan. Disamping efektifitas permainan, semakin lama sebuah tim menguasai bola, maka semakin besar kemungkinan tim tersebut mencetak skor. Sepak bola juga dikenal sebagai olahraga yang keras dan cepat. Permainan ini tidak pernah bisa terlepas dari benturan. Karena itu, pemain dituntut cerdas dan cepat dalam mengambil keputusan ketika bermain untuk meminimalisasi benturan agar tidak mudah terlilit cedera. Terlebih dalam pertandingan yang syarat akan emosi dan gengsi seperti el- classico di spanyol, derby melladoninna di italia, laga klasik liga inggris ataupun dalam pertandingan-pertandingan bergengsi tinggi lainnya. Akan sangat banyak hal-hal yang dapat memanaskan dan meningkatkan tempo pertandingan tersebut. Menurut Alan Gibbson dan Jhon Cartwright (2000: 7) yang menyatakan "Sepakbola adalah permainan passing dan running", dari pola yang sukar diramalkan dan selalu berubahubah menuntut kesadaran tinggi dari semua 
pemain dan menuntut suatu kemampuan untuk membuat keputusan yang tepat dan bertindak cepat tanpa menunda-nunda.

Ketepatan passing/umpan dan pengambilan keputusan yang cepat dan tepat juga sangat berperan penting dalam sepak bola. Disamping menciptakan permainan yang cantik, hal ini juga memunculkan efektifitas bermain. Tentunya untuk melakukan itu semua tidaklah mudah. Pemain harus mengikuti sesi latihan yang berat dan jangka waktu yang panjang, agar dapat bekerja sama dengan baik dan mengetahui pergerakan terhadap pemain sesama tim

Latar belakang dari permasalahan penelitian ini adalah masih banyak siswa yang kurang tepat dalam melakukan passing dalam permainan sepak bola, passing siswa yang dilakukan belum terarah dengan sasaran yang ditentukan. Dalam pelaksanaan di lapangan, peserta ekstrakurikuler pada cabang sepakbola khususnya, dalam melakukan ketepatan passing belum begitu terlatih sehingga ketika bermain masih susah untuk mempertahankan bola, sehingga ketika melakukan passing masih sering salah sasaran atau tidak tepat sasaran. Dalam hal ini salah satu penyebabnya adalah karena para peserta ekstrakurikuler melakukan latihan teknik dasar passing, siswa jenuh ketika melakukan teknik dasar secara monoton, dan mereka lebih memilih bermain langsung dengan menggunakan lapangan, karena menurut mereka itu lebih menarik. Selain itu, masih banyak siswa yang belum paham dengan tehnik menendang.

Salah satu metode latihan yang dirasa mampu meningkatkan ketepatan umpan tersebut adalah dengan small-sided games. Dengan metode small-sided games yang didesain dalam bentuk hampir sama dengan situasi permainan yang sesungguhnya, melibatkan seluruh pemain dalam suatu bentuk latihan, diharapkan bentuk latihan sesuai dengan kebutuhan di lapangan. Untuk membantu pelatih mengatur pelatihan agar efektif dan efisien adalah melalui pengaturan besar kecilnya ukuran arena latihan atau dengan pembatasan-pembatasan jumlah pemain dan aktivitas,misalnya permainan satu atau dua sentuhan(luxbacher, 1999:xiii-xiv). Smallsided games diharapkan mampu membuat pemain semakin cepat dalam bereaksi dan menentukan keputusan, misalnya setelah menerima umpan, pemain diharapkan bisa memberikan atau menyambung umpan kepada rekan satu timnya dengan cepat dan tepat. Karena arena lapangan yang kecil dan pembatasan sentuhan terhadap bola,maka ruang gerak semakin sempit. Hal tersebut akan membuat pemain mau tidak mau harus cepat bereaksi agar bola tidak terebut oleh lawan dan diberikan kepada teman satu tim dengan baik. Dengan metode latihan ini,diharapkan nantinya pemain dapat mengambil keputusan dalam memberikan umpan (passing) dengan cepat dan tepat saat bermain dalam permainan yang sesungguhnya. Ini akan berpengaruh baik untuk individu ataupun tim. Berdasarkan uraian diatas, maka penulis ingin mengetahui dan mengadakan penelitian dengan judul pengaruh latihan small sided games terhadap ketepatan passing ekstrakurikuler sepakbola.

\section{METODE PENELITIAN}

Studi literatur adalah mencari referensi teori yang relefan dengan kasus atau permasalahan yang ditemukan. Referensi ini dapat dicari dari buku, jurnal, artikel laporan penelitian, dan situs-situs di internet. studi literatur ini adalah terkoleksinya referensi yang relefan dengan perumusan masalah.

\section{PEMBAHASAN}

Latihan small-sided games dapat mempengaruhi sentuhan terhadap bola lebih banyak, waktu untuk bermain lebih banyak, dapat meningkatkan keterampilan (skill). lebih banyak mengambil keputusan dalam suatu permainan, banyak memainkan bertahan dan menyerang, keterlibata pemain dalam permainan lebih banyak, dan dapat meningkatkan kondisi fisik. 
Sepakbola memerlukan keterampilan passing, dribbling, dan shooting. Latihan small sided games yang dilakukan di fokuskan untuk meningkatkan ketepatan passing siswa. Siswa mengalami kenaikan melakukan passing tepat.

Metode latihan small sided games dalam penelitian ini dapat berpengaruh terhadap perkembangan passing controlling dan shooting. Hal ini didukung oleh pernyataan Ganesha Putera (dalam Komarudin, 2013) yaitu latihan small sided games dapat digunakan dalam proses latihan peningkatan daya tahan aerobik dalam permainan sepakbola karena dalam latihan small-sided gamesmencakup aspek teknik, taktik dan fisik. Dengan harapan akan mengasah keterampilan bermain sepakbola baik secara individu maupun tim. Dalam penilitian ini peneliti memberikan aturan dimana peserta hanya boleh melakukan dua kali sentuhan setiapa satu orang pemain dan setelah tim melakukan lima kali passing pemain yang menyentuh bola terakhir diharuskan melakukan shooting ke gawang. Latihan small sided games sangat baik digunakan karena latihan tersebut lebih memfokuskan pemain dengan aturan yang diberlakukan.

Tiga poin utama latihan tersebut sesuai dengan yang dijelaskan oleh Harsono (2005), bahwa setiap pelaksanaan program latihan haruslah menyangkut program latihan yang sistematis, berulang-ulang, dan beban selalu bertambah untuk meningkatkan kualitas fisik, teknik dan mental. Latihan shooting dalam small sided games ini dilakukan setelah peserta melakukan passing sebanyak lima kali sehingga peserta lebih terbiasa melakukan shooting ke sasaran yang dituju.

Berdasarkan pelaksanaan perlakuan latihan small sided games di atas, yang dilakukan secara sistematis, berulang ulang, dan beban bertambah, serta menggunakan prinsip dan tahapan latihan yang sesuai prosedur tersebut, maka terbukti nyata bahwa latihan Small sided games memberi pengaruh yang signifikan terhadap keterampilan passing.

\section{DAFTAR PUSTAKA}

Abdul Karim. (2018). Pengaruh Latihan Small Sided Games Terhadap Peningkatan Ketepatan Passing Dengan Kaki Bagian Dalam Pada Siswa Peserta Ekstrakurikuler Sepakbola Mts Ali Maksum Bantul. Skripsi. Program Studi Pjkr Universitas Negeri Yogyakarta

Bayu Arisdianto. (2012). Pengaruh Small Sided Games Terhadap Passing Kaki Bagian Dalam Pada Permainan Sepakbola. Jurnal Program Studi Pendidikan Guru Sekolah Dasar Pendidikan Jasmani Universitas Pendidikan Indonesia

Bondarev, D.V. (2011). "Factors influencing cardiovascular responses during small-sided games performed with recreational purposes". Journal of Physical Education Ukraine, 2011, 2, 115-118

Charaka Raga Wardana. (2018). Pengaruh Latihan Small-Sided Games Terhadap Keterampilan Passing, Controlling Dan Shooting Peserta Ekstrakurikuler Sepakbola Smk Negeri 1 Tegalsari Kabupaten Banyuwangi. Jurnal Kejaora, Volume 3 Nomor 2, November 2018, Issn 2541-5042

Charles, T \& Rook, S. (2012). 1001 sesi latihan sepak bola untuk pemain muda. Jakarta Barat: PT Indeks.

Dharmawan Effendy. (2015). Pengaruh Metode Latihan Small-Sided Games Terhadap Ketepatan Umpan (Passing) Pada Pemain Sepak Bola Melati Muda Bantul. Skripsi. Jurusan Pendidikan Olahraga Universitas Negeri Yogyakarta

Fathurohman. (2017). Pengaruh Latihan Small Sided Games Terhadap Ketepatan Passing Dalam Permainan Sepak Bola. Skirpsi. Uin Banten

Fendi Ilmawan. (2013). Pengaruh Latihan Small-Sided Games Terhadap Ketepatan Passing Siswa Sdn 1 Maron Yang Mengikuti Ekstrkurikuler Sepakbola. Skripsi. Jurusan Pendidikan Olahraga Universitas Negeri Yogyakarta 